\title{
Driving nucleolar assembly
}

\author{
Kathleen L. McCann, ${ }^{1}$ and Susan J. Baserga ${ }^{1,2,3,4}$ \\ ${ }^{1}$ Department of Genetics, ${ }^{2}$ Department of Molecular Biophysics and Biochemistry, ${ }^{3}$ Department of Therapeutic Radiology, Yale \\ University School of Medicine, New Haven, Connecticut 06520, USA
}

In this issue of Genes \& Development, Grob and colleagues (pp. 220-230) identify the minimal molecular requirements to assemble a fully functional nucleolus in human cells and demonstrate the importance of the nucleolar transcription factor upstream binding factor (UBF) as a mitotic bookmark at the ribosomal DNA (rDNA).

In all eukaryotes, the nucleolus is an essential, nonmembrane-bound organelle within the nucleus. Assembled around the ribosomal DNA (rDNA), the nucleolus is the site of ribosome biogenesis. In addition to its role in making ribosomes, the nucleolus functions in other important cellular processes, including stress sensing, regulation of the cell cycle, and proliferation and assembly of ribonucleoprotein complexes (Boisvert et al. 2007). As such, it is not surprising that changes in nucleolar structure or function are associated with many human diseases, including cancer and an increasing number of ribosomopathies (Boisvert et al. 2007; McCann and Baserga 2013). Thus, understanding the regulation of nucleolar assembly and function is of great importance both as a fundamental question of cell biology and to human health.

Eighty years ago, the Nobel prize winner McClintock (1934) first observed that the nucleolus assembles around specific chromosomal features, termed nucleolar organizer regions (NORs). NORs, which contain repeated arrays of the rDNA, are easily identified in metaphase chromatin spreads as secondary constrictions or regions where the chromatin is less condensed. In human cells, NORs are found on the short arms of the five acrocentric chromosomes (Hernandez-Verdun et al. 2010). While a single NOR is capable of directing nucleolar assembly, several active NORs often coalesce to form a single nucleolus. Many human cells typically have one to three nucleoli per cell (Savino et al. 2001).

Interestingly, nucleolar assembly and function in human cells is regulated in a cell cycle-dependent manner. When cells enter mitosis and the nuclear membrane

[Keywords: nucleolus; nucleolar organizer region (NOR); UBF; mitotic bookmarking; pseudo-NOR; neo-NOR]

${ }^{4}$ Corresponding author

E-mail susan.baserga@yale.edu

Article is online at http://www.genesdev.org/cgi/doi/10.1101/gad.237610.114. breaks down (open mitosis), transcription of the ribosomal RNA (rRNA) is inhibited, and the nucleolus disassembles. Upon completion of mitosis, rRNA transcription is reinitiated within the NOR, ribosome biogenesis factors are recruited, and the nucleolus is assembled. Only NORs that are actively engaged in transcription can direct nucleolar assembly (Hernandez-Verdun 2011). Consequently, the nucleolus truly appears to be "an organelle formed by the act of building a ribosome" (Melese and Xue 1995).

To begin to reveal the molecular mechanisms of nucleolar formation, McStay's laboratory (Mais et al. 2005; Grob et al. 2014) has applied synthetic biology. In an earlier report, they introduced $6.4 \mathrm{~kb}$ of DNA repeat sequences from the intergenic spacer of the Xenopus ribosomal gene into a noncanonical site in the human genome. This nontranscribed region of Xenopus rDNA efficiently binds both Xenopus and human upstream binding factor (UBF). They found that ectopic arrays (16-328 repeats) of this rDNA fragment, which does not contain the sequence for the rRNA, was sufficient to recruit the RNA polymerase I (Pol I) transcription factor UBF as well as other components of the Pol I machinery to sites outside the nucleolus. They were able to detect secondary constrictions as in endogenous NORs; they therefore termed these structures pseudo-NORs (Mais et al. 2005). However, even though components of the Pol I machinery were recruited, pseudoNORs were transcriptionally inactive and did not form functional nucleoli.

In this issue of Genes \& Development, Grob et al. (2014) use a similar approach to generate synthetic, functional nucleoli. They integrated a 20.4-kb cassette that contains Xenopus UBF-binding sites, a human rDNA promoter, and a mouse rDNA transcription unit into metacentric chromosomes of human cells (Fig. 1). Similar to pseudo-NORs, the ectopic arrays (50-180 transcription units), or neo-NORs, formed secondary constrictions and recruited both UBF and the Pol I machinery. Unlike pseudo-NORs, the neo-NORs were transcriptionally active, properly processed the pre-rRNA, and assembled ribosomes as fully functional neonucleoli (Grob et al.

(C) 2014 McCann and Baserga This article is distributed exclusively by Cold Spring Harbor Laboratory Press for the first six months after the fullissue publication date (see http://genesdev.cshlp.org/site/misc/terms.xhtml). After six months, it is available under a Creative Commons License (Attribution-NonCommercial 3.0 Unported), as described at http:// creativecommons.org/licenses/by-nc/3.0/. 


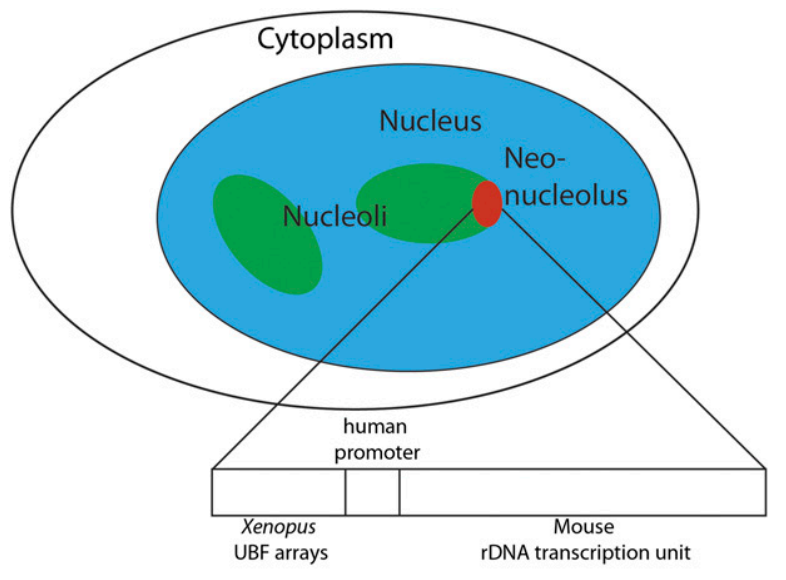

Neo-NOR Cassette

Figure 1. A synthetic NOR can drive formation of functional nucleoli. The integration of a neo-NOR cassette /which contains UBF-binding arrays from Xenopus, a human rDNA promoter, and a mouse rDNA transcription unit) into a metacentric chromosome is sufficient to drive formation of a functional nucleolus. Strikingly, unlike pseudo-NORs, the neo-NOR can coalesce with endogenous NORs to form large nucleoli. In this schematic, the nucleus is in blue, the nucleolus is in green, and the neo-NOR is in red.

2014). Additionally, neo-NORs coalesced with endogenous NORs into large nucleoli. Thus, unlike pseudoNORs, neo-NORs direct nucleolar assembly in human cells. This finding supports the fundamental significance of rDNA transcription in nucleolar formation.

The necessity of a transcriptionally competent rDNA unit in directing ectopic nucleolar assembly has been observed previously. The introduction of a single, ectopic rDNA repeat into the genome of Drosophila melanogaster was sufficient to drive rRNA transcription and assembly of "mininucleoli" (Karpen et al. 1988). Interestingly, even though endogenous rDNA genes are usually found tandemly repeated in heterochromatin in eukaryotes, neither is necessary for nucleolar formation in Drosophila. Similarly, the neo-NOR cassette was capable of driving nucleolar assembly in human cells regardless of the chromosomal context (Grob et al. 2014). While tandem repetition and heterochromatin localization are not strict requirements for nucleolar biogenesis, these conserved characteristics are likely to be important for other nucleolar mechanisms.

In addition to providing strong evidence for the importance of rDNA transcription in directing nucleolar assembly, the neo-NOR cassette aided in determining the role of UBF in nucleolar formation. Secondary constrictions in chromosomes can be observed in both pseudoNORs and neo-NORs (Mais et al. 2005; Grob et al. 2014). Since the binding sites for UBF are shared between the two rDNA cassettes that constitute these synthetic NORs, it suggests that UBF may be critical. Indeed, upon siRNA depletion of UBF, secondary constrictions were lost, indicating that UBF plays an essential role in maintaining NOR competency through mitosis (Grob et al. 2014).
Based on these results, the McStay laboratory (Mais et al. 2005; Grob et al. 2014) has developed a model for the role of UBF and rDNA transcription in nucleolar formation. In this model, UBF acts as a mitotic bookmark (Zaidi et al. 2010) by remaining associated with the rDNA repeats of NORs throughout mitosis. The presence of UBF and, consequently, the Pol I machinery at NORs throughout mitosis enables the rapid resumption of rDNA transcription and the efficient reformation of the nucleolus in early G1. As demonstrated with neo-NORs, UBF-binding sites coupled with rDNA transcription units are the minimal requirements for driving the assembly of functional nucleoli (Fig. 1).

Nevertheless, a number of unsolved mysteries underlying nucleolar formation and function still remain. For example, endogenous NORs are located in heterochromatic regions. In contrast, neo-NORs form functional nucleoli in euchromatin. So, why are endogenous NORs found exclusively in heterochromatin? Their location in heterochromatin is thought to be important for other elements of nucleolar biology, including the maintenance of genome stability, but this has yet to be definitively proven.

Additionally, it is not known what determines the number of cellular nucleoli. Human diploid cells have the potential for up to 10 nucleoli, as there are NORs on each of the five different acrocentric chromosomes. However, only one to three nucleoli are observed, likely due to the coalescence of multiple NORs into one nucleolus (Savino et al. 2001). Interestingly, unlike pseudoNORs, neo-NORs coalesce into nucleoli with endogenous NORs, suggesting that the sequences necessary for this process are present in the neo-NOR cassette. The mechanisms regulating nucleolar number or driving NOR coalescence remain largely unknown. Given the utility of the synthetic approach in identifying the minimal sequence requirements for nucleolar assembly, this approach will be a powerful tool to address these other aspects of nucleolar biology.

\section{Acknowledgments}

We thank Sam Sondalle for reading this perspective. This work was supported by National Institutes of Health GM 52581 and T32 GM 007499.

\section{References}

Boisvert FM, van Koningsbruggen S, Navascues I, Lamond AI. 2007. The multifunctional nucleolus. Nat Rev Mol Cell Biol 8: $574-585$.

Grob A, Colleran C, McStay B. 2014. Construction of synthetic nucleoli in human cells reveals how a major functional nuclear domain is formed and propagated through cell division. Genes Dev (this issue). doi: 10.1101/gad.234591.113.

Hernandez-Verdun D. 2011. Assembly and disassembly of the nucleolus during the cell cycle. Nucleus 2: 189-194.

Hernandez-Verdun D, Roussel P, Thiry M, Sirri V, Lafontaine DL. 2010. The nucleolus: Structure/function relationship in RNA metabolism. Wiley Interdiscip Rev RNA 1: 415-431.

Karpen GH, Schaefer JE, Laird CD. 1988. A Drosophila rRNA gene located in euchromatin is active in transcription and nucleolus formation. Genes Dev 2: 1745-1763. 
Mais C, Wright JE, Prieto JL, Raggett SL, McStay B. 2005. UBFbinding site arrays form pseudo-NORs and sequester the RNA polymerase I transcription machinery. Genes Dev 19: 50-64.

McCann KL, Baserga SJ. 2013. Genetics. Mysterious ribosomopathies. Science 341: 849-850.

McClintock B. 1934. The relation of a particular chromosomal element to the development of the nucleoli in Zea mays. $Z$ Zellforsch Mikrosk Anat 21: 294-326.

Melese T, Xue Z. 1995. The nucleolus: An organelle formed by the act of building a ribosome. Curr Opin Cell Biol 7: 319324.

Savino TM, Gebrane-Younes J, De Mey J, Sibarita JB, Hernandez-Verdun D. 2001. Nucleolar assembly of the rRNA processing machinery in living cells. I Cell Biol 153: $1097-1110$.

Zaidi SK, Young DW, Montecino MA, Lian JB, van Wijnen AJ, Stein JL, Stein GS. 2010. Mitotic bookmarking of genes: A novel dimension to epigenetic control. Nat Rev Genet 11: 583-589. 


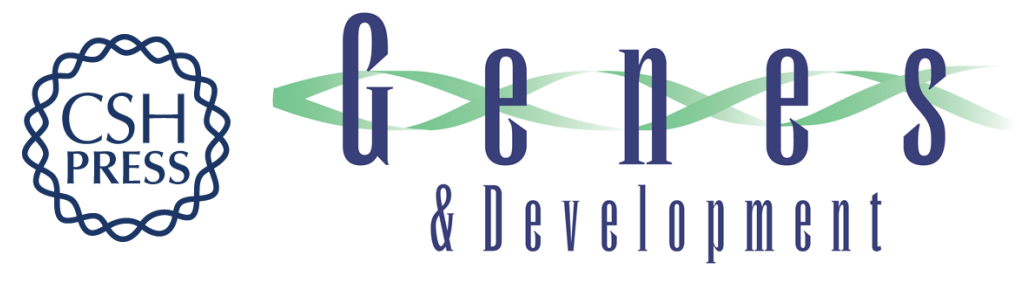

\section{Driving nucleolar assembly}

Kathleen L. McCann and Susan J. Baserga

Genes Dev. 2014, 28:

Access the most recent version at doi:10.1101/gad.237610.114

Related Content Construction of synthetic nucleoli in human cells reveals how a major functional nuclear domain is formed and propagated through cell division Alice Grob, Christine Colleran and Brian McStay

Genes Dev. February , 2014 28: 220-230

References This article cites 10 articles, 4 of which can be accessed free at: http://genesdev.cshlp.org/content/28/3/211.full.html\#ref-list-1

Articles cited in:

http://genesdev.cshlp.org/content/28/3/211.full.html\#related-urls

Creative This article is distributed exclusively by Cold Spring Harbor Laboratory Press for the first Commons License six months after the full-issue publication date (see http://genesdev.cshlp.org/site/misc/terms.xhtml). After six months, it is available under a Creative Commons License (Attribution-NonCommercial 3.0 Unported), as described at http://creativecommons.org/licenses/by-nc/3.0/.

Email Alerting Receive free email alerts when new articles cite this article - sign up in the box at the top Service right corner of the article or click here.

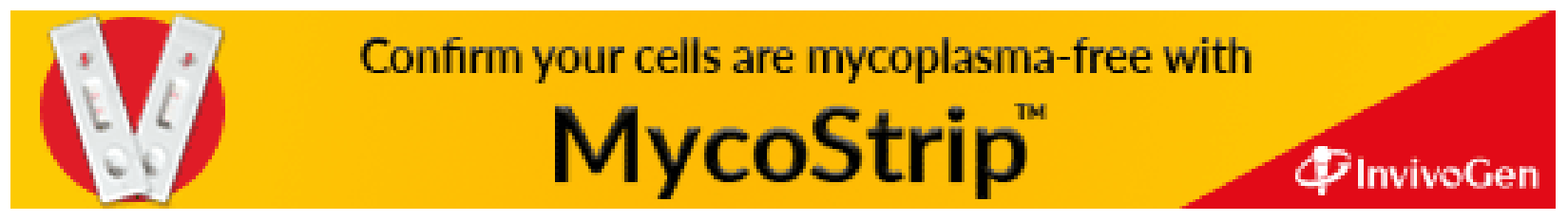

